\title{
Steps for the decision making based on the statistical analyses
}

OOpen acess

${ }^{1}$ Grupo de estudos de Enfermagem Baseada em Evidências- EBE.

Faculdade de Medicina do ABC,

Santo André, Brasil

${ }^{2}$ Laboratório de Epidemiologia e Análise de dados da Faculdade de Medicina do ABC, Santo André, Brasil

Corresponding author: winterfigueiredo@gmail.com

Manuscript received: May 2017

Manuscript accepted: October 2017

Version of record online: December 2017

\author{
Francisco Winter dos Santos Figueiredo', ${ }^{1,}$, Fernando Adami'
}

Keywords: biostatistics, scientific research, statistical analyses 
In a recent article, Baker ${ }^{1}$ makes reference to the statement released by the American Statistical Association (ASA) about the risk of making decisions based primarily on p-values by researchers, which has become a common practice followed by a considerable number of scientists worldwide.

Definitely, this is a highly relevant topic meriting considerable discussion, as the search for statistic results can lead to certain issues, from the scientific viewpoint, and the clinical perspective, as well. As an example, we can mention publication bias, which can occur in systematic reviews - as a consequence of the fact that studies whose results are not statistically significant, have slim chances of publication, compared with those whose results have such significance - and the possible release of drugs without any therapeutic efficacy for general marketing.

There is respectable literature related to the use and misuse of p-values. Additionally, $\mathrm{Nuzzo}^{2}$ warns about this rooted culture. As a possible solution, the author suggests that researchers should consider the confidence intervals of estimates and statistical adjustment for confounding variables and replicability of experiments. Thus, such practices are directly related to researchers' lack of knowledge regarding study designs, complete lack of planning for the performance of trials and, particularly, with poor understanding of the meaning of p-values.

Another important fact often overlooked by researchers is that the making of decisions about the acceptance or rejection of a hypothesis involves interval estimates and probability values, as well as the applicability of biological, clinical, and epidemiological results, which are as important as the estimates obtained.

On this matter, we point out the statement made by Leek \& Peng 3 , "p-values are only the tip of the iceberg." The design and conduction of a successful study has many stages, and decisions made earlier during data analysis have greater impacts on results.

Since the first step is defining the research question, such a research question should be defined clearly for accurate statistical analyses. Well-known methodologies are highly useful in the process of defining research questions, such as $\operatorname{PICOS}^{4}$ (Population, Intervention, Comparison, Outcome, Study Design) for experimental analytical studies, PEOS (Population, Exposure, Outcome, Study Design) for observational analytical studies, and POS (Population, Outcome and Study Design) for descriptive studies.

Once the research question has been defined clearly, the next step is to establish a plausible model from the theoretical viewpoint, supporting the possible analyses that should be conducted. After knowing the data distribution, the best analyses for addressing the research question that meets the assumptions of the statistical tests and their relationship with the theoretical model that has already been defined ${ }^{5}$ should be selected.

After conducting the most appropriate test, point and interval estimates should be obtained using the statistical models that facilitate adjustment for the variables that might confound the obtained results ${ }^{5}$.

The analysis of $p$-values alone should not be the last stage in decision-making, as presented in the flowchart.
Figure 1. Steps for the decision making based on the statistical analyses

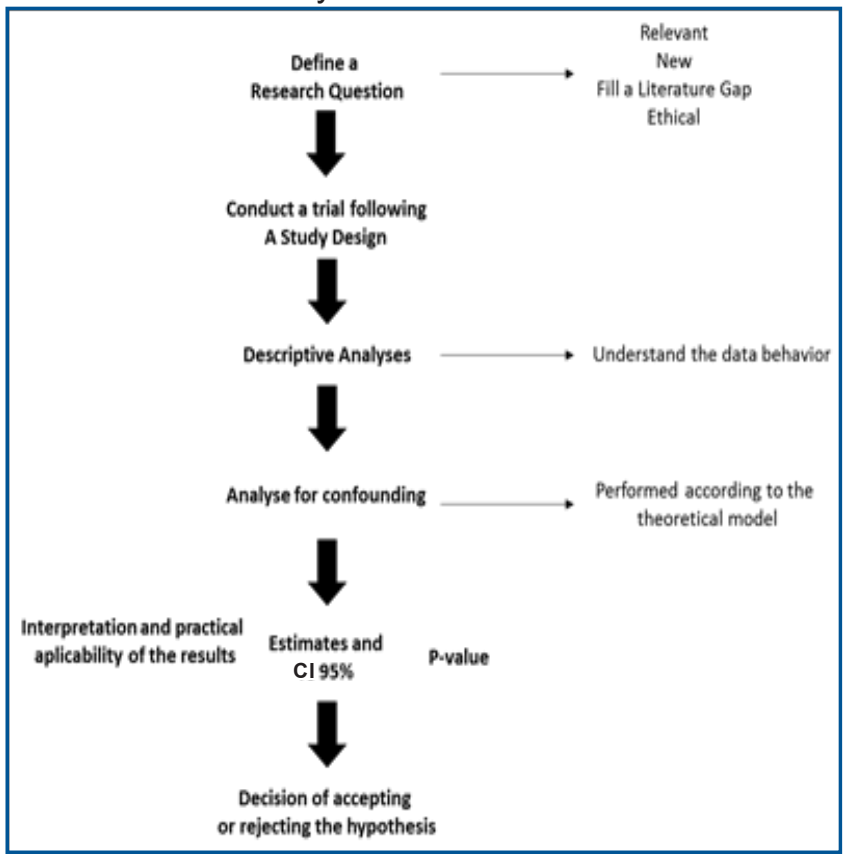

Cl 95\%: 95\% Confidence Interval

The p-value is only one of the parameters that should be analyzed, and therefore, we developed the framework described in this paper to guide researchers and students in their research. Therefore, the making of the decision of accepting or rejecting a hypothesis should be guided by scientific literature and the practical knowledge and experience of the researcher. 


\section{REFERENCES}

1. Baker M. Statisticians issue warning on $P$ values Statement aims to halt missteps in the quest for certainty. Nature. 2016;531(7593):151. DOI: http://dx.doi.org/10.1038/nature.2016.19503

2. Nuzzo R. Statistical errors: $P$ values, the 'gold standard' of statistical validity, are not as reliable as many scientists assume. Nature. 2014;506(7487):150-2. DOI: http://dx.doi.org/10.1038/506150a

3. Leek JP, Peng PD. P values are just the tip of the iceberg. Nature. 2015;520(7549):612. DOI: http://dx.doi.org/10.1038/520612a

4. Boudin F, Nie JY, Bartlett JC, Grad R, Pluye R, Dawes M. Combining classifiers for robust PICO element detection. BMC Med Infor Decision Making. 2010;10:29. DOI: https://doi.org/10.1186/1472-6947-10-29

5. Hauber AB, González JM, Groothuis-Oudshoorn CG, Prior T, Marshall DA, Cunningham C, et al. Statistical methods for the analysis of discrete choice experiments: a report of the ISPOR Conjoint Analysis Good Research Practices Task Force. Value Health. 2016;19(4):300-15. DOI: https://doi.org/10.1016/j.jval.2016.04.004

\section{Resumo}

Pesquisadores e estudantes em formação ficam confusos quando precisam concluir suas pesquisas com base nos resultados encontrados. Entretanto, por vários fatores, acabam respondendo suas perguntas de pesquisas baseados principalmente nos valores de " $p$ ". Neste artigo, apresentamos um quadro para decisão baseada na análise estatística e descrevemos aspectos fundamentais para a decisão adequada. Além disso, também discutimos aspectos relacionados a construção da evidência científica, como por exemplo, como a pergunta de pesquisa e a análise estatística estão relacionadas. Por fim, desenvolvemos um quadro com o passo a passo para tomada de decisão baseada na análise estatística. Com esse artigo, pretendemos contribuir para o desenvolvimento das pesquisas e orientar os pesquisadores e estudantes no que diz respeito a esse tema tão importante e negligenciado.

Palavras-chave: bioestatística, pesquisa científica, análise estatística

${ }^{\odot}$ The authors (2017), this article is distributed under the terms of the Creative Commons Attribution 4.0 International License (http://creativecommons.org/licenses/by/4.0/), which permits unrestricted use, distribution, and reproduction in any medium, provided you give appropriate credit to the original author(s) and the source, provide a link to the Creative Commons license, and indicate if changes were made. The Creative Commons Public Domain Dedication waiver (http://creativecommons.org/publicdomain/ zero/1.0/) applies to the data made available in this article, unless otherwise stated. 